\title{
COMPARATIVE ANALYSIS OF FATAL DELIBERATE SELF-HARM IN THE YEAR 2000 AND 2015- AN AUTOPSY STUDY
}

\author{
Rajeev V. M1, Jinesh P. S2, Ravikumar $K^{3}$
}

${ }_{1}^{1}$ Associate Professor, Department of Forensic Medicine, Government Medical College, Kottayam. ${ }^{2}$ Senior Lecturer, Department of Forensic Medicine, Government Medical College, Kottayam. 3Junior Resident, Department of Forensic Medicine, Government Medical College, Kottayam.

\section{BACKGROUND}

ABSTRACT

The state of Kerala has attained very high standards of health care at the National level, but the high rate of suicide is a major health problem which has to be tackled. The suicide rate in Kerala in $2014(24.9$ per 100,000) is much higher than the National average of 10.6. The rate hit the top in the year 2001 - 02 with 28.8, after which it started to decline and by 2012 came down to 24.3. According to data provided by the Kerala State Mental Health Authority, the population in Kerala as per 2011 census is $33,900,662$. Total number of suicides in Kerala in 2014 is 8446, the suicide rate being 24.9 per lakh population. Fatal deliberate self-harm (suicide) is a self-chosen method to end one's own life. It may be due to momentary behavioural aberration or the person may be harbouring the suicidal tendency for a prolonged period. Suicide is best viewed as a symptom rather than a disease. The underlying disease may be depression of one type or the other and is considered to be treatable by pharmacological or psychological means.

Aims and Objectives-

Comparative study of 'Fatal Deliberate Self-Harm' (DSH) in the year 2000 and 2015 regarding the-

1. Methods adopted, and

2. Distribution of population groups.

\section{MATERIALS AND METHODS}

This is a retrospective case series study, in which all cases of 'fatal deliberate self-harm' brought for autopsy during the year 2000 and 2015 were analysed and compared with each other.

Sample Size- There were 614 cases of 'Fatal Deliberate Self-Harm' in the year 2000 and 542 cases in the year 2015.

Source Population- All cases of 'Fatal Deliberate Self-Harm,' brought for autopsy in the Department of Forensic Medicine, Govt. Medical College, Kottayam in the year 2000 and 2015.

Inclusion Criteria- All Known cases of death due to DSH.

Exclusion Criteria- All Unknown bodies of death due to DSH.

Data Collection- Baseline data like age, sex, religion and history of any disease were collected from the requisition provided by the investigating police officer. Other parameters like method adopted for suicide and the age group distribution were analysed. In the case of poisoning, the type of poison was entered based on the report of the Chief Chemical Examiner to Government of Kerala.

Analysis- Data collected was entered in MS Excel and analysed using SPSS version 15.

Statistical Test- Chi-square test.

\section{RESULT}

Total number of post-mortem examinations in Dept. of Forensic Medicine, Govt. Medical College, Kottayam in the year 2000 was 1457, out of which 614 cases (42.1\%) were fatal cases of deliberate self-harm (DSH). In 2015, total number of cases were 1665, in which fatal cases of DSH were 542 (32.6\%). In the year 2000 out of 614 cases of suicides brought for autopsy males constituted $409(66.6 \%)$ cases and females 205 (33.4\%), while in 2015 out of 542 cases of suicides males constituted 390 (72.0\%) cases and females 152 (28\%). In 2000, total number of fatal DSH cases was 614. Out of these, 315 cases were poisoning (51\%), 190 cases were hanging (31\%), 67 were burns (11\%), 19 were drowning (3\%), 12 were railway occurrence (2\%) and 11 were other types (2\%) including cut throat ( 4 cases), firearm ( 3 cases) and blast ( 2 cases). In 2015 out of a total of 542 fatal DSH cases, 340 were hanging (63\%), 136 were poisoning (25\%), 41 were burns (7.6\%), 13 were drowning $(2.6 \%), 6$ were railway (1\%) and 6 were other types (1\%). In the year 2000 among the 614 cases of DSH there were $315(51.3 \%)$ of poisoning, whereas in the year 2015 among the 542 cases of DSH poisoning constituted only $136(25.1 \%)$ cases.

\section{CONCLUSION}

The most vulnerable age group for committing fatal DSH in year 2000 was 21 - 30 years followed by 31 - 40 years. The most vulnerable age group for committing fatal DSH in year 2015 was 41 - 50 years followed by 51 - 60 years. The most common method adopted for committing fatal DSH was poisoning followed by hanging in year 2000. The most common method adopted for committing fatal DSH was hanging followed by poisoning in year 2015. The most frequently used poison for fatal DSH was Carbamate followed by Organophosphorous poisoning in year 2000. Religion wise Hindus were the most common victims of fatal DSH followed by Christians and Muslims who were only minimally involved in fatal DSH in both 2000 and 2015.

\section{KEYWORDS}

Fatal Deliberate Self-Harm, Suicide, Autopsy. 
HOW TO CITE THIS ARTICLE: Rajeev VM, Jinesh PS, Ravikumar K. Comparative analysis of fatal deliberate self-harm in the year 2000 and 2015- an autopsy study. J. Evolution Med. Dent. Sci. 2017;6(94):6898-6904, DOI: 10.14260/jemds/2017/1495

'Financial or Other Competing Interest': None.

Submission 04-11-2017, Peer Review 29-11-2017,

Acceptance 04-12-2017, Published 18-12-2017.

Corresponding Author:

Dr. Rajeev V. M,

Associate Professor

Department of Forensic Medicine,

Government Medical College,

Kottayam.

E-mail: drrajeevvm3056@gmail.com

DOI: $10.14260 /$ jemds/2017/1495

\section{(c) $($ ) $\$$}

\section{BACKGROUND}

Fatal deliberate self-harm (Suicide) is a self-chosen method to end one's own life. It may be due to momentary behavioural aberration or the person may be harbouring the suicidal tendency for a prolonged period. The state of Kerala has attained very high standards of health care at the National level, but the high rate of suicide is a major health problem which has to be tackled. The state has achieved improvements in material conditions of living, reflected in indicators of social development, comparable to developed countries, even though the per capita income is low. Achievements such as low levels of infant mortality and population growth and high levels of literacy and life expectancy have been considered characteristic of Kerala model of development. However, the suicide rate in Kerala in 2014 (24.9 per 100,000) is much higher than the National average of 10.6. The rate hit the top in the year $2001-02$ with 28.8, after which it started to decline and by 2012 came down to 24.3. The reduction was mainly achieved through the women empowerment initiatives of the Government, selfhelp groups, suicide prevention intervention centres and awareness programs.

Suicide is best viewed as a symptom rather than a disease. The underlying disease may be depression of one type or the other and is considered to be treatable by pharmacological or psychological means. ${ }^{1}$ About 800,000 people commit suicide every year. ${ }^{2}$ Among these 135,000 are residents of India. ${ }^{3}$ Between 1987 and 2007, the suicide rate increased from 7.9 to 10.3 per 100,000 people in India ${ }^{4}$ with higher rates in the southern and eastern states of India. ${ }^{5}$ According to WHO, age standardised suicide rate in India is 16.4 per 100,000 for women (6 $6^{\text {th }}$ highest in the world and 25.8 for men ranking $22^{\text {nd }) .6}$

According to data provided by the Kerala State Mental Health Authority (www.kmsha.org), the population in Kerala as per 2011 census is $33,900,662$. Total number of suicides in Kerala in 2014 is 8446 , the suicide rate being 24.9 per lakh population. Among the districts in Kerala, Malappuram district has the least rate of suicide (8.3/ lakh) and Kollam and Thiruvananthapuram have the highest (41.3 and 41.1 respectively).

Aims and Objectives

Comparative Study of 'Fatal Deliberate Self-Harm' (DSH) in the Year 2000 and 2015 regarding the,

1. Methods adopted, and

2. Distribution of population groups.

\section{MATERIALS AND METHODS}

This is a retrospective case series study, in which all cases of 'fatal deliberate self-harm' brought for autopsy during the year 2000 and 2015 were analysed and compared with each other.

\section{Sample Size}

There were 614 cases of 'fatal deliberate self-harm' in the year 2000 and 542 cases in the year 2015.

\section{Source Population}

All cases of 'fatal deliberate self-harm,' brought for autopsy in the Department of Forensic Medicine, Govt. Medical College, Kottayam in the year 2000 and 2015.

\section{Inclusion Criteria}

All known cases of death due to DSH.

\section{Exclusion Criteria}

All unknown bodies of death due to DSH.

\section{Data Collection}

Baseline data like age, sex, religion and history of any disease were collected from the requisition provided by the investigating police officer. Other parameters like method adopted for suicide and the age group distribution were analysed. In the case of poisoning, the type of poison was entered based on the report of the Chief Chemical Examiner to Government of Kerala.

\section{Analysis}

Data collected was entered in MS excel and analysed using SPSS version 15.

\section{Statistical Test}

Chi-square test.

\section{RESULTS}

Total number of post-mortem examinations in Dept. of Forensic Medicine, Govt. Medical College, Kottayam in the year 2000 was 1457, out of which 614 cases (42.1\%) were fatal cases of deliberate self-harm (DSH). In 2015, total number of cases were 1665, in which fatal cases of DSH were $542(32.6 \%)$.

For finding out the decrease in fatal DSH cases in proportion to the number of cases in the year 2015 when compared to the year 2000, chi-square test was done. The obtained chi-square value is 30.641 . This shows that decrease in number of fatal DSH in 2015 is significant.

\begin{tabular}{|c|c|c|c|c|}
\hline No. of Cases & Year 2000 & \% & Year 2015 & \% \\
\hline Fatal DSH cases & 614 & \multirow{3}{*}{42.1} & 542 & \\
\cline { 1 - 3 } $\begin{array}{c}\text { Total Autopsy } \\
\text { cases }\end{array}$ & 1457 & & 1665 & \\
\cline { 1 - 2 } \\
brought for Autopsy
\end{tabular}

Chi-square $=30.641 ; \mathrm{p}<0.00$ 


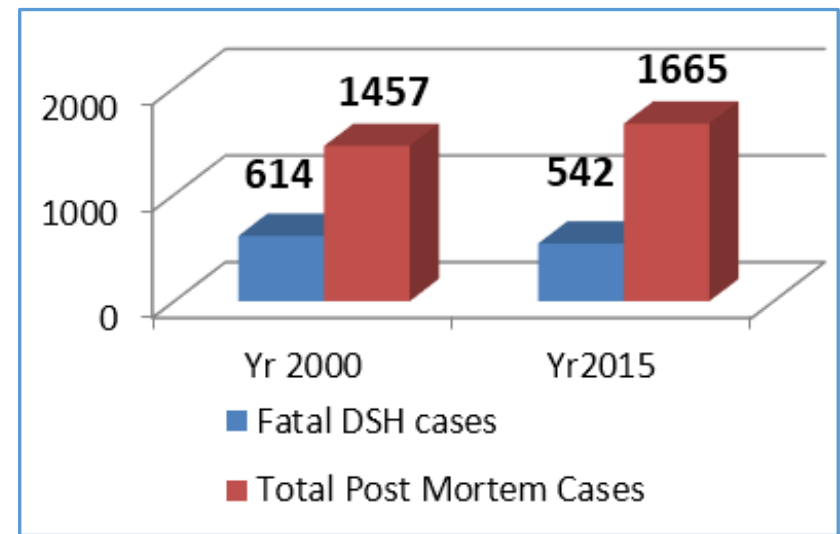

Figure 1. Fatal DSH among Total Cases brought for Autopsy

Sex Wise distribution of Fatal DSH Cases in 2000 and 2015

In the year 2000 out of 614 cases of suicides brought for autopsy, males constituted 409 (66.6\%) cases and females 205 (33.4\%); while in 2015 out of 542 cases of suicides, males constituted 390 (72.0\%) cases and females 152 (28\%). The chi-square obtained is (chi-square $=3.931 ; p<0.05$ ). This shows that there is significant association between gender distribution of fatal DSH cases in the year 2000 and 2015.

\begin{tabular}{|c|c|c|c|c|}
\hline Sex & $\begin{array}{c}\text { Year 2000 } \\
(\mathbf{N = 6 1 4})\end{array}$ & $\%$ & $\begin{array}{c}\text { Year 2015 } \\
(\mathbf{N = 5 4 2 )}\end{array}$ & $\%$ \\
\hline Male & 409 & $66.6 \%$ & 390 & $72.0 \%$ \\
\hline Female & 205 & $33.4 \%$ & 152 & $28 \%$ \\
\hline Total & $\mathbf{6 1 4}$ & $\mathbf{1 0 0 . 0 0 \%}$ & $\mathbf{5 4 2}$ & $\mathbf{1 0 0 . 0 0 \%}$ \\
\hline \multicolumn{4}{|c|}{ Table 2. Sex Wise Distribution of DSH in the } \\
Year 2000 and 2015 \\
\hline
\end{tabular}

Chi-square $=3.931 ; \mathrm{p}<0.05$

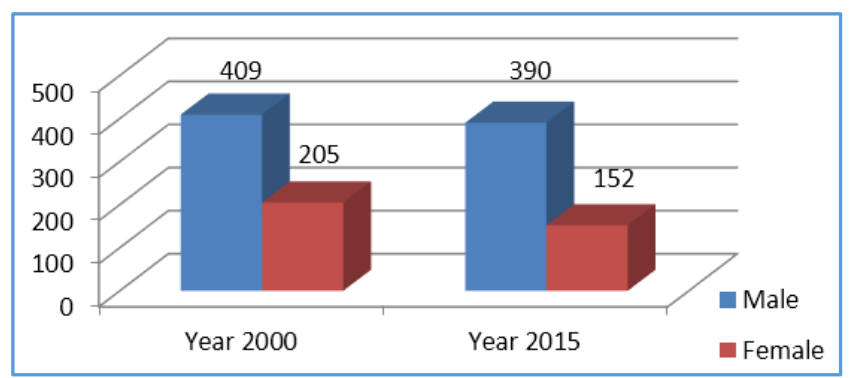

Figure 2. Sex Wise Distribution DSH in the Year 2000 and 2015

Type of DSH based on the Method Adopted

In 2000, total number of fatal DSH cases were 614. Out of this 315 cases were poisoning (51\%), 190 cases were hanging (31\%), 67 were burns (11\%), 19 were drowning (3\%), 12 were railway occurrence $(2 \%)$ and 11 were other types $(2 \%)$ including cut throat ( 4 cases), firearm ( 3 cases) and blast ( 2 cases). In 2015 out of a total of 542 fatal DSH cases, 340 were hanging (63\%), 136 were poisoning (25\%), 41 were burns (7.6\%), 13 were drowning (2.6\%), 6 were railway (1\%) and 6 were other types $(1 \%)$. The method adopted shows that while hanging was the preferred method of $30.9 \%$ of sample in the year 2000 , it was preferred by $62.7 \%$ of sample during the year 2015. The chi-square obtained is 125.522. This shows that there is significant difference between distribution of methods adopted in fatal DSH cases in the year 2000 and 2015.

\begin{tabular}{|c|c|c|c|c|}
\hline $\begin{array}{c}\text { Method Adopted } \\
\text { for DSH }\end{array}$ & $\begin{array}{c}\text { Year 2000 } \\
\text { (N= 614) }\end{array}$ & $\mathbf{\%}$ & $\begin{array}{c}\text { Year 2015 } \\
\text { (N= 542) }\end{array}$ & \% \\
\hline Hanging & 190 & 30.9 & 340 & 62.7 \\
\hline Poisoning & 315 & 51.3 & 136 & 25.1 \\
\hline Burns & 67 & 10.9 & 41 & 7.6 \\
\hline Drowning & 19 & 3.1 & 13 & 2.4 \\
\hline Railway & 12 & 2.0 & 6 & 1.1 \\
\hline Others & 11 & 1.8 & 6 & 1.1 \\
\hline Total & $\mathbf{6 1 4}$ & $\mathbf{1 0 0}$ & $\mathbf{5 4 2}$ & $\mathbf{1 0 0}$ \\
\hline
\end{tabular}

Table 3. Types of DSH according to the Method Adopted

Chi-square $=125.522 ; \mathrm{p}<0.000$

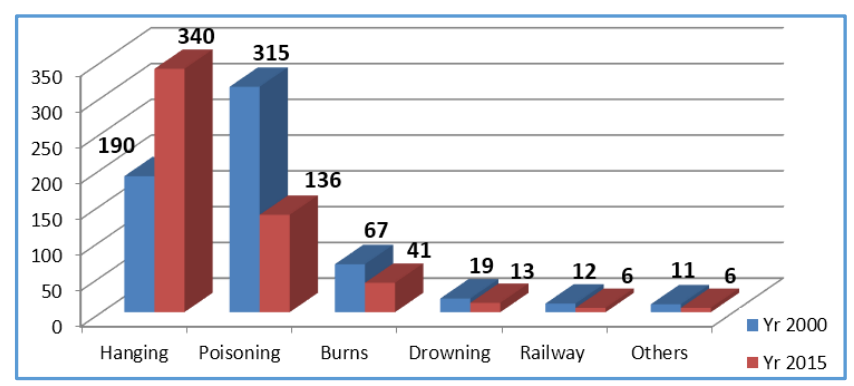

Figure 3. Types of DSH according to Method Adopted

Distribution of Poisoning Cases in the Year 2000 and 2015

In the year 2000 among the 614 cases of DSH there were 315 (51.3\%) of poisoning, whereas in the year 2015 among the 542 cases of DSH, poisoning constituted only $136(25.1 \%)$ cases. The chi-square obtained is 83.112, which was significant.

\begin{tabular}{|c|c|c|c|c|}
\hline Frequency & $\begin{array}{c}\text { Year 2000 } \\
\text { (N= 614) }\end{array}$ & $\mathbf{\%}$ & $\begin{array}{c}\text { Year 2015 } \\
\text { (N= 542) }\end{array}$ & \% \\
\hline Poisoning & 315 & 51.3 & 136 & 25.1 \\
\hline Other Cases & 299 & 48.7 & 406 & 74.9 \\
\hline Total & 614 & 100 & 542 & 100 \\
\hline \multicolumn{5}{|c|}{ Table 4. Distribution of Poisoning Cases in the } \\
Year 2000 and 2015 \\
\hline
\end{tabular}

Chi-square $=83.112 ; \mathrm{p}<0.000$

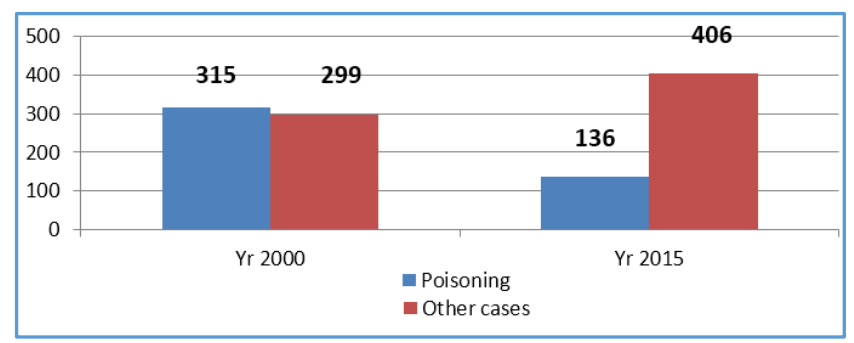

Figure 4. Distribution of Poisoning Cases in the Year 2000 and 2015

Type of Poison used for DSH in the Year 2000 and 2015 There were 315 cases of poisoning in 2000 and 136 cases of poisoning in 2015. In 2000 out of these 315 cases of poisoning, 139 cases were carbamate poisoning (44.1\%), 88 were organophosphate poisoning (27.9\%), 43 were formic acid poisoning $(13.7 \%)$ and 45 were other types of poisoning (14.3\%), which includes 8 rodenticide poisoning cases, 7 organochlorine poisoning and 5 cases of odollam poisoning. In 2015 out of the total 139 cases of poisoning 68 were organophosphate poisoning (48.9\%), 24 were formic acid 
poisoning (17.2\%), 19 were carbamate poisoning (13.7\%) and 25 were other types of poisoning (18.0\%) which includes 11 odollam poisoning, 6 cases of drug overdose and 4 cases of rodenticides.

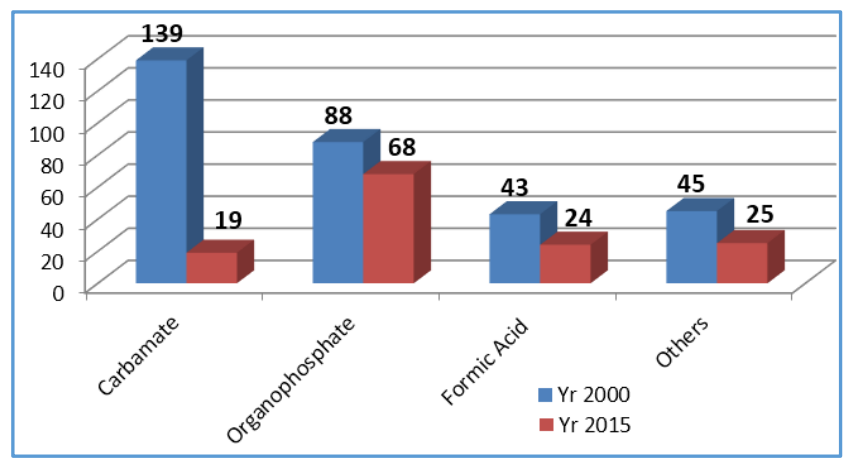

Figure 5. Distribution of Types of Poison used in the Year 2000 and 2015

Religion Wise distribution of Fatal DSH in the year 2000 and 2015

Hindus constituted the highest number of cases, 410 (67\%) in 2000 and 344 (64\%) in 2015, followed by Christians 188 (31\%) in 2000 and 178 (33\%) in 2015. There were 16 (2.6\%) Muslims in 2000 and 20 (3.7\%) in 2015.

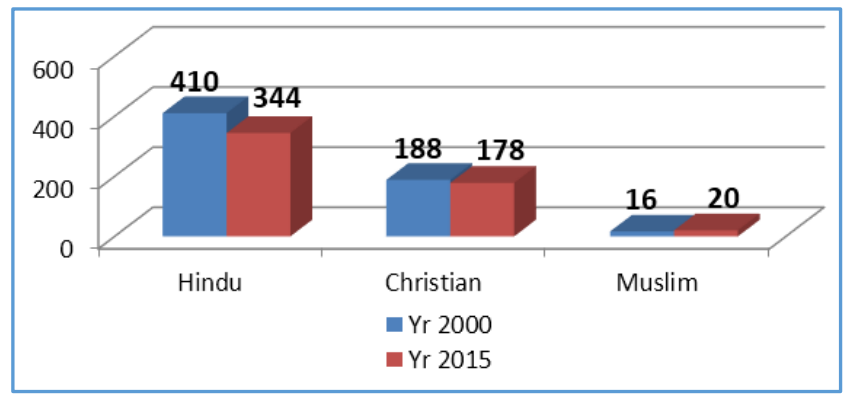

Figure 6. Religion Wise distribution of Fatal DSH in the Year 2000 and 2015

Age-Wise distribution of DSH Cases during 2000 and 2015

The maximum number of fatal DSH was in the age group of 21 - 30 in the year 2000 of 144 cases $(23.5 \%)$ followed by the age group 31 - 40 of 133 cases (21.70\%). But in 2015, the highest number of cases is in the 41 - 50 age group of 124 cases $(22.80 \%)$ followed by age group 51 - 60 age group of $106(19.6 \%)$. There is an increase in fatal DSH in the age group $11-20$ from $6.70 \%$ in 2000 to $10.3 \%$ in 2015 . The chisquare obtained is 30.321 , which is significant showing that there is significant association between age and year.

\begin{tabular}{|c|c|c|}
\hline Age Group & 2000 (N= 614) & $\mathbf{2 0 1 5}(\mathrm{N}=\mathbf{5 4 2})$ \\
\hline $11-20$ & $41(6.70 \%)$ & $56(10.30 \%)$ \\
\hline $21-30$ & $144(23.50 \%)$ & $76(14 \%)$ \\
\hline $31-40$ & $133(21.70 \%)$ & $87(16 \%)$ \\
\hline $41-50$ & $113(18.40 \%)$ & $124(22.80 \%)$ \\
\hline $51-60$ & $99(16.10 \%)$ & $106(19.70 \%)$ \\
\hline $61-70$ & $47(7.70 \%)$ & $56(10.30 \%)$ \\
\hline $71-92$ & $37(6 \%)$ & $37(6.80 \%)$ \\
\hline Total & $\mathbf{6 1 4}(100 \%)$ & $\mathbf{5 4 2 ( 1 0 0 \% )}$ \\
\hline Table 5. Age-Wise Distribution of Fatal DSH Cases during \\
the Year 2000 and 2015 \\
\hline
\end{tabular}

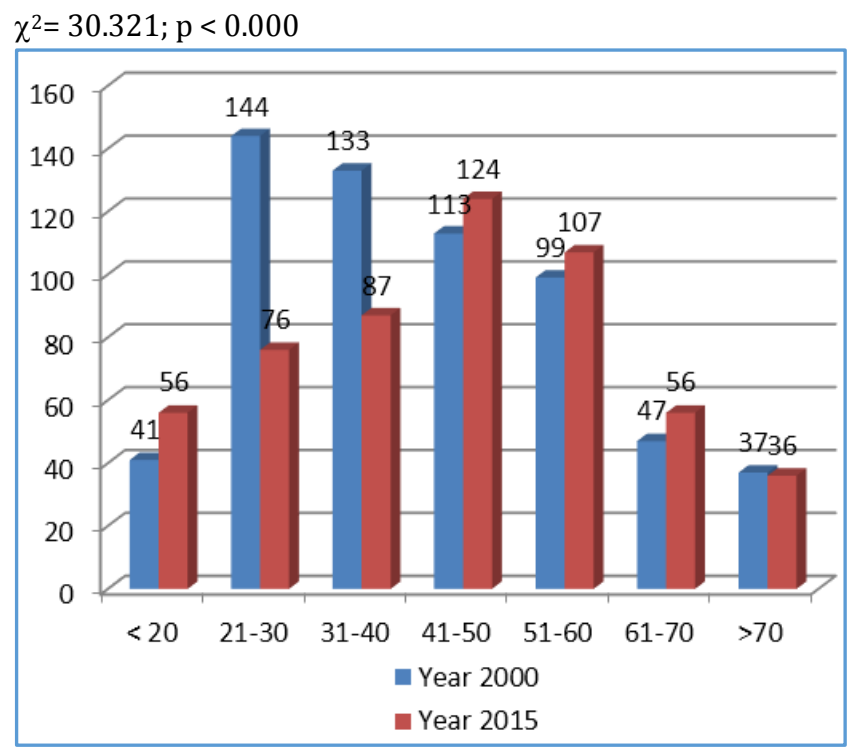

Figure 7. Age-Wise Distribution of Fatal DSH Cases during the Year 2000 and 2015

Marital Status

\begin{tabular}{|c|c|c|}
\hline & Yr 2000 (N= 614) & Yr 2015 (N= 542) \\
\hline Married & $442(72 \%)$ & $395(73 \%)$ \\
\hline Not Married & $172(28 \%)$ & $147(27 \%)$ \\
\hline Table 6. Marital Status of Victims of Fatal DSH in 2000 and \\
2015 \\
\hline
\end{tabular}

$\chi^{2}=12.83 ; \mathrm{p}<0.00$

Majority of cases in both 2000 and 2015 were married. Chisquare is significant.

\begin{tabular}{|c|c|c|}
\hline & Yr 2000 (n= 205) & Yr 2015 (n= 152) \\
\hline Dowry Death & $42(20 \%)$ & $19(12.5 \%)$ \\
\hline $\begin{array}{c}\text { Total No. of } \\
\text { Females }\end{array}$ & 205 & 152 \\
\hline \multicolumn{2}{|c|}{ Table 7. Distribution of Alleged Dowry Death } \\
in the Year 2000 and 2015 \\
\hline
\end{tabular}

$\chi^{2}=8.124 ; p<0.00$

Percentage of Dowry death in 2000 was 20 and 2015 was 12.5. Chi-square is significant.

\section{Education}

\begin{tabular}{|c|c|c|}
\hline & Yr $2000(\mathrm{~N}=614)$ & Yr $2015(\mathrm{~N}=542)$ \\
\hline Primary & $310(50.5 \%)$ & $315(58.5 \%)$ \\
\hline More than primary & $304(49.5 \%)$ & $227(41.5 \%)$ \\
\hline \multicolumn{3}{|c|}{$\begin{array}{c}\text { Table 8. Educational Status of Victims of Fatal DSH } \\
\text { in the Year } 2000 \text { and } 2015\end{array}$} \\
\hline
\end{tabular}

Residential Area

\begin{tabular}{|c|c|c|c|}
\hline $\begin{array}{c}\text { Residential } \\
\text { Area }\end{array}$ & $\begin{array}{c}\text { Yr 2000 } \\
(\mathbf{N = 6 1 4 )}\end{array}$ & $\begin{array}{c}\text { Yr 2015 } \\
(\mathbf{N = 5 4 2 )}\end{array}$ & T-value \\
\hline Rural & $379(61.7 \%)$ & $317(58.5 \%)$ & 1.10 \\
\hline Urban & $235(38.3 \%)$ & $225(41.5 \%)$ & 1.10 \\
\hline \multicolumn{3}{|c|}{ Table 9. Residential Status of Victims of Fatal DSH } \\
in the Year 2000 and 2015 \\
\hline
\end{tabular}


Percentage of rural population in 2000 was $62 \%$ and that of urban was $38 \%$ and in 2015 they were $59 \%$ and $41 \%$ respectively. Chi-square was not significant.

\section{Occupation}

\begin{tabular}{|c|c|c|c|}
\hline Occupation & $\begin{array}{l}\text { Yr } 2000 \\
(\mathrm{~N}=614)\end{array}$ & $\begin{array}{l}\text { Yr } 2015 \\
(\mathrm{~N}=542)\end{array}$ & T-value \\
\hline Manual Labourer & $219(35.7 \%)$ & $250(46 \%)$ & 3.56 \\
\hline Salaried & $37(6 \%)$ & $46(8.5 \%)$ & 1.64 \\
\hline Unemployed & $265(43.2 \%)$ & $145(26.8 \%)$ & 3.19 \\
\hline Business & $56(9.1 \%)$ & $29(5.4 \%)$ & 2.40 \\
\hline Student & $37(6 \%)$ & $72(13.3 \%)$ & 4.24 \\
\hline Total & $614(100 \%)$ & $542(100 \%)$ & \\
\hline \multicolumn{4}{|c|}{$\begin{array}{c}\text { Table 10. Occupational Status of Victims of Fatal } \\
\text { DSH in the Year } 2000 \text { and } 2015\end{array}$} \\
\hline
\end{tabular}

$\chi 2=54.359 ; \mathrm{p}<0.00 ;$ Significant.

\begin{tabular}{|c|c|c|c|}
\hline & $\begin{array}{c}\text { Yr 2000 } \\
(\mathbf{n = 4 0 9 )}\end{array}$ & $\begin{array}{c}\text { Yr 2015 } \\
(\mathbf{n = 3 9 0 )}\end{array}$ & T-value \\
\hline Alcoholic & $169(41 \%)$ & $141(36 \%)$ & 1.45 \\
\hline \multicolumn{4}{|r|}{ Table 11. Alcohol Abuse among Males of Fatal DSH } \\
\hline
\end{tabular}

In 2000 (41\%) of males were alcoholic and in 2015 (36\%) were alcoholic. Percentage of drug abuse in 2000 was 3.3 and 2015 was 3.7.

\begin{tabular}{|c|c|c|c|}
\hline $\begin{array}{c}\text { Financial } \\
\text { Problem }\end{array}$ & $\begin{array}{c}\text { Yr 2000 } \\
(\mathbf{N = 6 1 4})\end{array}$ & $\begin{array}{c}\text { Yr 2015 } \\
(\mathbf{N}=\mathbf{5 4 2})\end{array}$ & T-value \\
\hline Present & $183(30 \%)$ & $82(15 \%)$ & 5.06 \\
\hline $\begin{array}{c}\text { No Financial } \\
\text { Problem }\end{array}$ & $431(70 \%)$ & $460(85 \%)$ & 6.05 \\
\hline
\end{tabular}

Table 12. Financial Problems of Victims of Fatal DSH

$\chi^{2}=35.279 ; \mathrm{p}<0.00$; Significant.

\section{Psychiatric Illness}

\begin{tabular}{|c|c|c|c|}
\hline $\begin{array}{c}\text { History of } \\
\text { Psychiatric } \\
\text { Illness }\end{array}$ & $\begin{array}{c}\text { Yr 2000 } \\
\text { (N=614) }\end{array}$ & $\begin{array}{c}\text { Yr 2015 } \\
\mathbf{( N = 5 4 2 )}\end{array}$ & T-value \\
\hline Present & $70(11 \%)$ & $72(13 \%)$ & 1.04 \\
\hline Absent & $544(89 \%)$ & $470(87 \%)$ & 0.87 \\
\hline Table 13. Financial Problems of Victims of Fatal DSH \\
\hline
\end{tabular}

$\chi 2=4.330 ; p<0.047 ;$ Not Significant.

In 2000 (28) have had history of love failure and in 2015 (23) have had love failure and all of them were adolescent/ young adults.

Physical, mental and sexual abuses cases were 17 in 2000 and 4 in 2015.

40 (7.4\%) have had conflicts with family members in 2000 and $74(12 \%)$ in 2015.

$70(13 \%)$ have had any type of major personal illness in 2000 and 91 (15\%) have had that in 2015.

In 2000 (15) cases (3\%) of DSH was taunting of parents and in 2015 (12) cases (2\%) were due to taunting of parents.

Cause of one fatal DSH in 2000 and three DSH in 2015 was infertility.

10 females (6.5\%) committed DSH in 2000 and 23 (11\%) committed DSH in 2015 due to nuisance from alcoholic husbands.

$9(1.5 \%)$ in 2000 and $13(2.4 \%)$ in 2015 were due to grief reaction, i.e. death of father/ mother.
Cause of 1 DSH in 2000 and 7 in 2015 were examination stress.

4 cases in 2000 and 6 in 2015 were due to job stress.

There were 10 cases of murder-suicide in 2000 and none was reported in 2015.

\section{DISCUSSION}

In the year 2000, the total number of cases brought for postmortem examination in the Department of Forensic Medicine, Govt. Medical College, Kottayam were 1457 of which 614 (42.1\%) were fatal cases of DSH and in 2015 out of 1665 cases fatal DSH were 542 (32.6\%). Even though the total number of cases in 2015 showed an increase of $14.3 \%$ over year 2000 , the number of fatal DSH cases had shown a decline of $11.7 \%$ in year 2015 .

In year 2000 males constituted $409(66.6 \%)$ cases and females 205 (33.4\%), whereas in year 2015 males were 390 (72\%) and females 152 (28\%). This shows a comparative decrease in the percentage of female cases of fatal DSH in 2015 than in 2000. Females are quite content to lead a life of their own and are subsumed within family. ${ }^{7}$ Even though suicidal ideas and tendencies are more prevalent among females, mortality from suicide is typically low in females than for males, a phenomenon described as gender paradox in suicides. ${ }^{8}$ There is an over representation of females in non-fatal suicidal behaviour and a preponderance of males in completed suicide. ${ }^{9}$

\section{Comparative Analysis of Age Wise distribution of Fatal DSH}

The maximum number of fatal DSH was in the age group of 21 - 30 in the year 2000 of 144 cases $(23.5 \%)$, followed by the age group 31 - 40 of 133 cases (21.70\%). But in 2015, the highest number of cases is in the $41-50$ age group of 124 cases (22.80\%), followed by age group $51-60$ of 106 $(19.6 \%)$. There is an increase in fatal DSH in the age group of 11 - 20 from $6.70 \%$ in 2000 to $10.3 \%$ in 2015 . There is a definite shift in the age distribution of victims of fatal DSH as observed above. In year 2000 the maximum number of victims were young adults, whereas in 2015 the pattern of age distribution changed completely to senior adults above 40 years and middle-aged people in financial and family problems could be the reason for the increased rate of suicides among the middle aged. Youth and middle-aged people were the prime groups taking recourse to path of suicides in India. These age groups account for 34\% and 32\% of suicides respectively. ${ }^{10}$ Suicide rates are lowest in persons under 15 years of age and highest in those aged 70 years or older for both men and women. ${ }^{11}$

Comparing the religion wise distribution of fatal DSH in 2000 and 2015, the trends appeared very similar. Hindus constituted $410(67 \%)$ of cases in 2000 , while it was 344 (64\%) in 2015. Christians constituted 188 (31\%) in 2000, while it was $178(33 \%)$ in 2015. There were only $16(2.6 \%)$ cases of Muslims in 2000, while it was 20 (3.7\%) cases in 2015. It is in conformity with the observation made by Kerala Mental Health Authority of suicide trends in Kerala, 2014, which stated that suicide rate in the district of Malappuram was the least (8.3 per lakh), as it is Muslim majority district. The suicide rate in Muslim population is very low compared to Christians and Hindus. Hindus appeared to be the most vulnerable religious group for committing suicide. The more 
religious the population is, the less vulnerable they become to suicide. Affiliation with Islam is associated with low suicide acceptability. ${ }^{12}$ There is a significant protective relationship between religiosity and suicide. 13

Majority of cases in both 2000 and 2015 were married. Marriage acts as a protective factor against suicide. Reported rates of suicide among various categories revealed that suicide rate is less in married people. ${ }^{14}$ Regarding educational status of victims of fatal DSH in year $200050.5 \%$ had primary education, while in $201558.5 \%$ had primary education. Persons with higher educational attainment had significantly increased odds ratio of dying from suicide than a natural cause in the age group of 15 - 54 years. ${ }^{15}$ In year 2000, 11\% of cases of fatal DSH had a history of known psychiatric illness, whereas in 2015 it was 13\%. The mentally ill persons are more prone to depression and they are susceptible to committing suicide. Mood disorders in which depression is the major example are the most common psychiatric condition associated with suicide. ${ }^{16}$ For those with bipolar depression, suicide risks are approximately 15 times that of general population. ${ }^{17}$

Regarding the method adopted for fatal DSH, there is a very significant change in the trend observed in year 2015 compared to 2000 . In the year 2000 , the most commonly employed method for fatal DSH was Poisoning 315 (51.3\%) cases, whereas in 2015 the most commonly employed method was hanging $340(62.7 \%)$ cases. Death due to Hanging was 190 (30.9\%) cases in 2000, whereas death due to Poisoning was 136 (25.1\%) cases in 2015. There were 67 (10.9\%) cases of death due to Burns in 2000, while it was 41 (7.6\%) in 2015. Death due to Drowning was 19 (3.1\%) and $13(2.4 \%)$ in 2000 and 2015 respectively. There were 12 (2\%) cases of death due to railway occurrence in 2000 , while it was $6(1.1 \%)$ cases in 2015 . Hanging is the predominant method of suicide in most countries. The highest proportion is around $90 \%$ in males and $80 \%$ in females. ${ }^{18}$

Regarding the type of poison used for fatal DSH, Carbamate, an organo-chloro compound was the most frequently employed type of poison in year 2000. There were 139 (44.1\%) cases of death due to carbamate poisoning in year 2000, while there were only $19(13.7 \%)$ cases of carbamate poisoning in 2015. The most commonly employed poison in 2015 was Organophosphorous (OP) compounds.

There were $68(48.9 \%)$ cases of OP poisoning in 2015 compared to $88(27.9 \%)$ cases in 2000. Formic acid was used in $43(13.7 \%)$ cases in 2000 , while it was $24(17.2 \%)$ cases in 2015. According to WHO 800,000 people die by suicide every year globally and about $30 \%$ of them kill themselves by consuming pesticides, most of them in low and middleincome countries. Since most suicides happen impulsively, easy access to substances such as pesticides can hugely affect a person's decision. Fatal DSH with pesticides accounts for about one-third of all suicides worldwide. ${ }^{19}$

\section{CONCLUSION}

1. The most vulnerable age group for committing fatal DSH in year 2000 was 21 - 30 years followed by 31 - 40 years.

2. The most vulnerable age group for committing fatal DSH in year 2015 was 41 - 50 years followed by 51 - 60 years.

3. The most common method adopted for committing fatal DSH was Poisoning followed by Hanging in year 2000.
4. The most common method adopted for committing fatal DSH was Hanging followed by Poisoning in year 2015.

5. The most frequently used poison for fatal DSH was Carbamate followed by Organophosphorous poisoning in year 2000 .

6. Religion wise, Hindus were the most common victims of fatal DSH followed by Christians and Muslims were only minimally involved in fatal DSH in both 2000 and 2015.

\section{REFERENCES}

[1] Suicide prevention (SUPRE). WHO, 2012. apps.who.int/iris/bitstream/10665/75166/1/97892 41503570_eng.pdf.

[2] Guptha SN, Gupta N, Ahmed N, et al. Suicide and its public health importance in India. Family Medicine \& Medical Science Research 2015;4(3):1-3.

[3] Vijayakumar L. Suicide and its prevention: the urgent need in India. Indian Journal of Psychiatry 2007;49(2):81-4.

[4] Lydia P. Suicides, some for separatist cause, Jolt India. The New York Times, March 30, 2010.

[5] Suicide rates-data by country. WHO, 2012. http://www.who.int/gho/mental_health/suicide_rate s/en/ on 30 November, 2015.

[6] Sudak BJ, Sadok VA, Ruiz P, et al. Ch-29. Kaplan \& Sadock's comprehensive text book of psychiatry. Vol 2. $9^{\text {th }}$ edn. Wolters Kluwer Health/Lippincott Williams \& Wilkins 2009:2717-31.

[7] Carnetto SS. Women and suicidal behaviour: a cultural analysis. American Journal of Orthopsychiatry 2008;78(2):259-66.

[8] Carnetto SS, Sakinofsky I. The gender paradox in suicide. Suicide Life Threat Behav 1998;28(1):1-23.

[9] Schrijvers DL, Bollen J, Sabbe BGC. The gender paradox in suicidal behavior and its impact on the suicidal process. Journal of Affective Disorders 2012;138(1-2):19-26.

[10] Suicides in India. National Crime Records Bureau. ncrb.in/stat publication/ADSI/ADSI 2014 ch.2 suicides pdf on 31.1.17

[11] Preventing suicide, A global imperative, WHO 2014:22.

apps.WHO.int/iris/bitstream/10665/131056/1/9789 241564779_eng.pdf on 1.2.17

[12] Stack S, Kposowa AJ. Religion and suicide acceptability, a cross-national analysis. Journal of Scientific Study of Religion 2011;50(2):289-306.

[13] Gearing RE, Lizardi D. Religion and suicide. Journal of Religion and Health 2009;48(3):332-41.

[14] Evans R, Emily R, Bryn J, et al. Gender, relationship breakdown and suicide risk: a review of research in western countries. Journal of Family Issues 2016;37(16):2239-64.

[15] Pompili M, Vichi M, Qin P, et al. Does the level of education influence completed suicide? A nationwide register study. Journal of Affective Disorders 2013;147(1-3):437-40.

[16] Jamison KR. Suicide and bipolar disorder. Journal of Clinical Psychiatry 2000;61(Suppl 9):47-51.

[17] Harris EC, Barraclough B. Suicide as an outcome for mental disorders. British Journal of Psychiatry 1997;170:205-28. 
[18] Gross VA, Weiss MG, Ring M, et al. Methods of suicide: international suicide patterns derived from the WHO mortality database. Bulletin of the World Health Organization 2008;86(9):726-32.
[19] Bertolete JM, Fleischmann A, Eddleston M, et al. Deaths from pesticide poisoning: a global response. British Journal of Psychiatry 2006;189(3):201-3. 